\title{
PENDIDIKAN KARAKTER DALAM ILUMINASI NASKAH BABAD PECINNA
}

\author{
Venny Indria Ekowati, Sri Hertanti Wulan, Aran Handoko, dan Nur Hanifah Insani \\ Fakultas Bahasa dan Seni, Universitas Negeri Yogyakarta \\ email: venny@uny.ac.id
}

\begin{abstract}
Abstrak: Pendidikan Karakter dalam Iluminasi Naskah Babad Pecinna. Penelitian ini bertujuan untuk: (1) mendeskripsikan representasi simbolsimbol dalam naskah Babad Pecinna, dan (2) menganalisis nilai-nilai pendidikan karakter dalam iluminasi naskah Babad Pecinna. Penelitian ini menggunakan metode penelitian filologi dan metode penelitian kualitatif. Metode penelitian filologi digunakan karena sumber data merupakan manuskrip Jawa. Metode kualitatif digunakan untuk menjelaskan representasi simbol yang digunakan dalam iluminasi naskah-naskah Jawa. Sumber data penelitian ialah iluminasi (wedana renggan) yang terdapat dalam naskah Babad Pecinna koleksi Museum Sonobudoyo Yogyakarta. Analisis data dilakukan dengan analisis hermeneutik dan heuristik. Hasil penelitian menunjukkan bahwa rerenggan yang tergambar dalam teks antara lain mulai dari kuncup bunga dan bunga yang sedang mekar yang menunjukkan sebagai penggambaran pola kehidupan. Rerenggan bunga yang sedang mekar jika dikaitkan dengan isi teks melambangkan adanya keindahan dalam cerita tersebut seperti watak baik seorang pemimpin sebagai cerminan pendidikan karakter. Pendidikan karakter yang terkandung di dalam iluminasi naskah Babad Pecinna adalah (1) kesucian hati seorang pemimpin, (2) kerendahan hati, (3) karakter berani, (4) karakter kepemimpinan berwibawa dan disegani oleh rakyat, dan (5) religius.
\end{abstract}

Kata kunci: makna simbolik, iluminasi, teks Serat Babad Pecinna

\begin{abstract}
Character Education in Babad Pecinna Manuscript Illumination. This study was aimed at describing the representation of symbols in Babad Pecinna manuscript, and (2) analyzing the values of character education in the illumination manuscript. This research used philology and qualitative research methods. The method of philological research was used since the data source is a Javanese manuscript. The qualitative method was used to explain the symbols used in the illumination of Javanese manuscripts. The source of research data is the illumination (wedana renggan) contained in the Babad Pecinna manuscript in Sonobudoyo Museum Yogyakarta. The data analysis was done by hermeneutic and heuristic analysis. The results show that the rerenggan depicted in the text, namely flower buds and blooming flowers as a life symbol. The blooming flower symbolizes the beauty and it is reflected good character of a leader as a good education character. Education characters contained in the text of the Babad Pecinna illumination are (1) sincerity (2) humility, (3) bravery, (4) the authority which is respected by the people, and (5) religiousness.
\end{abstract}

Keywords: symbolic meanings, illumination, Babad Pecinna manuscript 


\section{PENDAHULUAN}

Kearifan lokal yang terkandung dalam suatu kebudayaan dapat dilacak kembali melalui peninggalan-peninggalan masa lampau. Salah satu peninggalan budaya masa lampau tersebut adalah naskah lama. Naskah lama berisi tentang berita hasil budaya pada masa lampau yang ditulis oleh para leluhur. Djamaris (2002: 3) menyatakan bahwa naskah ialah semua bahan tulisan tangan peninggalan nenek moyang, yang ditulis di atas kertas, lontar, kulit kayu, dan rotan. Naskah di Indonesia sangat banyak jumlahnya dan tersebar di berbagai daerah. Di Yogyakarta salah satunya, naskah ada yang disimpan di museum, perpustakaan, perseorangan ataupun universitas. Hal ini didukung dengan keberadaan Kraton Yogyakarta sebagai pusat budaya sehingga kraton menjadi salah satu skriptoria yang paling produktif dalam penulisan naskah Jawa.

Sebagai salah satu peninggalan yang sangat berharga, masyarakat perlu mempelajari dan memahami isi naskah. Hal ini perlu dilakukan agar masyarakat mengetahui dengan jelas cara hidup manusia pada masa lampau. Baried (1985: 94) menyatakan bahwa naskah menjadi puncak kekayaan tempat menggali kejadian dan peristiwa yang telah terajadi pada masa lampau. Dengan kata lain naskah lama merupakan sumber utama yang penting bagi penyelidikan bahasa, sejarah, agama, perdaban, kebudayaan, dan politik masyarakat Nusantara pada masa lampau.

Mempelajari dan memahami naskah lama tentu bukan dengan cara sembarangan. Diperlukan metode ilmiah khusus untuk mengkaji naskah tersebut, yakni dengan menggunakan ilmu filologi. Secara etimologi, filologi berasal dari bahasa Yunani philos yang berarti cinta dan logos yang berarti kata (Baried, 1985: 1). Dalam perkembangannya filologi kemudian diartikan sebagai suatu disiplin ilmu yang mendasarkan kerjanya pada bahan tertulis dan bertujuan mengungkapkan maknanya dalam segi kebudayaan (Baried, 1985: 3). Objek dari kajian filologi sendiri adalah kandungan atau muatan naskah yang disebut dengan teks. Teks dari isi yaitu ide-ide atau amanat yang akan disampaikan oleh pengarang kepada pembacanya (Baried, 1985: 56). Dapat disimpulkan bahwa untuk bisa memahami dan mempelajari naskah lama, membutuhkan penelitian filologi.

Naskah yang menjadi sasaran kerja filologi merupakan suatu keutuhan yang dapat menyampaikan pesan atau amanat. Pengarang naskah tidak hanya menuangkan pesan atau amanat teks melalui aksara saja, namun juga melalui sebuah ilustrasi yang digambarkan dalam teks. Ilustrasi tersebut tidak hanya sekedar untuk hiasan ataupun keindahan, namun juga memiliki filosofi atau makna tersendiri yang tentunya tidak lepas dari isi teks. Ilustrasi tersebut dikenal dengan nama iluminasi.

Iluminasi merupakan unsur pendukung keindahan dalam suatu naskah. Gallop dan Arps (Safari, 2015: 309) menyatakan bahwa padanan kata iluminasi dalam bahasa Indonesia adalah seni sungging, sementara di Yogyakarta disebut renggan wadana. Iluminasi adalah seni yang ditekankan untuk lebih mempercantik suatu objek daripada mengklarifikasi atau menjelaskan isi suatu teks (Bland, 1969: 16). Safari (2015) dalam jurnalnya yang berjudul "Iluminasi dalam Naskah Cirebon" menjelaskan bahwa kedudukan iluminasi terhadap naskah itu penting, karena iluminasi menjadi salah satu media estetika dan sarana eksplanasi bagi teks yang terdapat pada naskah.

Pada awalnya, istilah iluminasi digunakan dalam penyepuhan emas pada beberapa halaman naskah untuk 
memperoleh keindahan dan biasanya ditempatkan sebagai hiasan atau gambar muka (frontispiece) naskah (Folsom dalam Zuriati, 2010: 1). Biasanya yang dihias adalah halaman muka naskah, namun pada perkembangannya iluminasi dipakai sebagai istilah untuk menyebut hiasan pada naskah yang mengandung berbagai macam warna dan pigmen metalik. Hiasan ini dimaksudkan untuk memperindah dan mempertinggi nilai suatu naskah (Folsom dalam Zuriati, 2010). Iluminasi juga telah berkembang lama dan banyak dibubuhkan pada surat raja-raja dari berbagai kerajaan di nusantara. Surat-menyurat antar kerajaan dengan menggunakan surat bergambar tercatat telah menjadi tradisi sejak tahun $1521 \mathrm{M}$ (Mu'jizah, 2009: 11).

Seluruh bagian hiasan pada naskah merupakan iluminasi. Iluminasi pada naskah-naskah Jawa secara umum meliputi: (1) hiasan bingkai yang berbentuk bangun berulang (wadana renggan) dan bingkai yang menyerupai bentuk gerbang atau gapura (wadana gapuran), yang umumnya ditempatkan secara berpasangan pada halaman ganda berhadapan; (2) hiasan pada bagian teks (rubrication), yang menghiasi bagian teks sebagai penanda bagian teks yang dianggap penting; dan (3) hiasan tanda baca atau pepadan yang menandai metrum dan lagu penting dalam akhir sebuah bait puisi (Saktimulya, 2012). Motif-motif yang digunakan dalam iluminasi adalah motif geometris, motif flora, motif fauna, motif manusia, motif benda-benda alam atau pemandangan, serta motif benda-benda teknologis dan kaligrafi. Motif umumnya disusun secara berulang dalam pola yang simetris, sehingga menghasilkan susunan iluminasi yang simetris, teratur, dan harmonis.

Iluminasi pada masa sekarang ini juga disebut sebagai border. Secara lebih rinci, Ekowati (2015: 95) menyatakan bahwa kajian terhadap iluminasi naskah Jawa akan mampu mengungkap: (1) metode wujud visualisasi naskah yang dapat menggambarkan nilai, norma, aturan hidup, pranata, dan daya cipta masyarakat pemilik manuskrip Jawa-Melayu, (2) proses penciptaan suatu produk seni rupa tradisional, (3) mengungkap faktor-faktor enkulturasi, akulturasi, sinkretisme, dan asimilasi yang disebabkan oleh persilangan budaya asing yang memberikan efek khusus yang tercermin dalam iluminasi, dan (4) ekspresi simbolik dari suatu komunitas masyarakat yang tercermin dalam iluminasi.

Folsom (1990: 40) menyatakan bahwa iluminasi adalah pembingkai teks yang tidak hanya berfungsi untuk memperindah, tetapi juga berhubungan dengan isi atau kandungan teks yang dibingkainya. Iluminasi suatu naskah jika dikaji secara cermat baik dari bentuk, objek, ukuran, komposisi, warna, dan simbol-simbol yang dihadirkan dapat mengungkap nilai-nilai unik masyarakat penciptanya. Berdasarkan tata ungkap gambar, akan didapatkan konsepsi cara menggambar, ungkapan komunikasi, dan pesan tersirat berupa simbol-simbol yang memiliki arti (Damayanti \& Suadi, 2011). Setiap simbol-simbol dalam iluminasi memiliki makna dan arti tersendiri, yang jika digabung-gabungkan akan membentuk suatu kesatuan cerita. Cerita yang disimbolkan dalam iluminasi pasti akan menghidupkan isi teks yang dibingkai tersebut. Dapat dikatakan pula, bahwa iluminasi seperti halnya amanat cerita, ia juga memiliki manfaat bagi para pembacanya.

Oleh karena iluminasi dan ilustrasi begitu penting dan masih minimnya penelitian filologi yang khusus membahas iluminasi, maka perlu kiranya untuk melakukan penelitan mengenai hal tersebut. Hal itu juga didasarkan melihat keberadaan naskah Jawa, terutama 
naskah-naskah di Perpustakaan Museum Sonobudoyo, yang memiliki cukup banyak naskah yang memuat iluminasi. Selain itu, iluminasi pada naskah yang tersimpan di Museum Sonobudoyo tersebut juga memiliki bentuk, motif, dan warna yang beragam dan menarik. Maka dari itu, untuk mengetahui ajaran budi pekerti yang terkandung di dalam gambar iluminasi naskah Jawa di Perpustakaan Museum Sonobudoyo perlu dilakukan suatu penelitian.

\section{METODE}

Sumber data penelitian ini adalah teks Babad Pecinna di Perpustakaan Museum Sonobudoyo Yogyakarta yang memuat iluminasi. Pengumpulan data dilakukan dengan analisis isi. Teknik analisis isi digunakan dalam pengumpulan data awal, yaitu dengan membaca teks Babad Pecinna secara lengkap. Kemudian teknik analisis isi ini dilanjutkan untuk pengumpulan data lanjutan, yaitu dengan membaca secara seksama bagian gambar pembentuk iluminasi kemudian menghubungkannya dengan isi teks tersebut. Teknik pengumpulan data dengan dokumentasi digunakan untuk mengumpulkan data iluminasi yang terdapat di dalam naskah.

\section{HASIL DAN PEMBAHASAN}

\section{Pendidikan Karakter dalam Iluminasi} Naskah Babad Pacinna

Iluminasi dalam manuskrip Jawa merupakan perwujudan aplikasi motif tradisional berusia ratusan tahun. Di antara sekian banyak manuskrip Jawa yang beriluminasi salah satunya adalah Babad Pecinna yang merupakan bagian dari penelitian kelompok yang bertujuan untuk mendeskripsikan 150 manuskrip Jawa beriluminasi koleksi museummuseum dan perpustakaan di Yogyakarta. Babad Pacinna merupakan salah satu naskah Jawa carik koleksi Perpustakaan Museum Sonobudoyo Yogyakarta. Penulis carik bernama Wedana Natadirja dan berdasarkan corak penulisannya ditulis di Yogyakarta dengan tahun penyalinan naskah yang dinyatakan pada kolofon depan (h. 5) penyalinan naskah dimulai tanggal 14 September 1885 dan selesai pada tanggal 11 November 1885 (h. 345r). Kronik sejarah Kerajaan Kartasura dan Surakarta mulai geger dengan Pacina dan berakhir dengan Kangjeng Pangeran Mangkubumi (kelak HB 1) bersiap untuk menyerang Panaraga. Teks dimulai dengan Tumenggung Mangunoneng bersama R.Megatsari menyerang dan menduduki Pati, kemudian menyarankan kepada Martapura yang telah mengangkat Mas Garendi sebagai Raja Demak agar raja berpindah dinobatkan di Pati sesuai dengan perintah Patih Natakusuma. Kemudian Martapura bergelar Adipati Sujanapura. Disambung dengan kronik sejarah Kerajaan Surakarta, penobatan Sunan Mentawis (HB 1) pada tahun 1749 (h. 255v) di Pambrekan. Berakhir dengan Pangeran Mangkubumi siap menyerang Panaraga setelah terjadi perselisihan dengan R.M. Said (kelak MN1) pada tahun 1753 (h. 344r) (Behrend, 1989: 44).

Babad Pacinna memuat iluminasi (wadana) yang ditulis dengan tinta Hindia Timur dengan bentuk dan gaya yang khas Yogyakarta. Iluminasi akan lebih bermanfaat ketika keberadaannya tidak hanya dipahami namun juga menjadi sebuah nilai-nilai yang patut diapresiasikan dalam kehidupan masyarakat. Seperti halnya nilai-nilai kehidupan yang baik dan sesuai dengan kaidahkaidah budaya lokal.

Dalam iluminasi terdapat berbagai macam motif ragam hias. Biasanya dalam satu iluminasi terdapat lebih dari dua atau tiga macam motif ragam hias. Motif ragam hias dalam iluminasi memiliki 
satu kesatuan, gambaran di dalam iluminasi tersebut sangat hidup. Ragam hias di dalamnya memiliki makna saling mengisi satu dan lainnya. Ada sebagian ragam hias yang memang keberadaannya sekedar pelengkap atau pemanis iluminasi tersebut. Namun, di setiap iluminasi pasti ada satu atau lebih bagian ragam hias yang sangat menunjukkan bahwa ragam hias tersebut mewakili kandungan teks. Kandungan teks iluminasi dalam naskah Babad Pacinna salah satunya adalah pendidikan karakter kepemimpinan.

Michael Novak dalam Lickona (2013) menjelaskan bawha karakter adalah perpaduan harmonis seluruh budi pekerti yang terdapat dalam ajaran agama, kisahkisah sastra, cerita orang bijak, dan orangorang berilmu sejak zaman dahulu hingga sekarang. Berdasarkan pendapat tersebut pendidikan karakter juga tertuang dalam naskah Babad Pacinna yang merupakan sebuah karya sastra kuno. Karakter mengalami pertumbuhan yang membuat suatu nilai menjadi budi pekerti, sebuah watak batin yang dapat diandalkan dan digunakan untuk merespon berbagai situasi dengan cara yang bermoral (Lickona, 2013:72). Pendidikan karakter bertujuan untuk menumbuhkan seorang individu menjadi pribadi yang memiliki integritas moral, bukan hanya sekedar sebagai individu, namun sekaligus mampu mengusahakan sebuah ruang lingkup kehidupan yang membantu setiap individu dalam menghayati integritas moralnya dalam tatanan kehidupan bermasyarakat (Koesoma, 2007). Berdasarkan pendapat tersebut, maka pendidikan karakter perlu diberikan kepada siapapun, mengingat pendidikan karakter sebagai suatu proses secara terus menerus demi kesempurnaan karakter setiap manusia.

Suherman (2014) menyatakan bahwa sembilan karakteryang perlu mendapatkan prioritas untuk ditumbuhkembangkan, antara lain: (1) cinta Tuhan dan kebenaran, (2) bertanggungjawab, disiplin, dan mandiri; (4) amanah dan jujur; (4) hormat dan santun; (5) kasih sayang, peduli, dan kerjasama; (6) percaya diri, kreatif, kerja keras, dan pantang menyerah; (7) adil dan kepemimpinan; (8) baik dan rendah hati; (9) toleran, cinta damai, dan persatuan. Di antara kesembilan karakter tersebut, pendidikan karakter yang dominan di dalam iluminasi naskah iluminasi Babad Pacinna adalah karakter kepemimpinan sebagaimana dideskripsikan berikut.

\section{Kesucian Hati Seorang Pemimpin}

Iluminasi/rerenggan pada halaman $004 \mathrm{v}$ dan 004r merupakan wedana gapura renggan dengan nama wedana milir kapatyan. Isi Teks Sêrat Babad Pecinna tersebut menceritakan waktu penulisan Babad Pecinna dan tentang sifat baik Tumenggung Jaganegara. Dalam iluminasi naskah babad Pecinna, karakter kesucian hati ini tampak pada simbol bunga. Secara keseluruhan, unsur iluminasi pada wedana renggan milir kapatyan berisi simbol bunga. Hal itu terlihat dari kondisi bunga ketika masih kuncup, mekar, sampai berkembang besar.

Bunga pada dasarnya memiliki makna filosofis agar seseorang mendapatkan keharuman, entah itu keharuman dari para leluhur ataupun keharuman namanya, karena sikap baik yang dimilikinya. Keharuman seseorang dapat tercapai tentu dari banyaknya doa dan berkah yang berlimpah dari para leluhur. Keharuman itulah yang nantinya dapat mengalir terus sampai ke anak cucu.

Gambar iluminasi/rerenggan dalam teks ini mengandung gambar kelopak dan mahkota bunga pada puncak gapura yang melambangkan bahwa terdapat sesuatu baru yang tumbuh dengan indah (Gambar 1). Kemungkinan yang dimaksud 


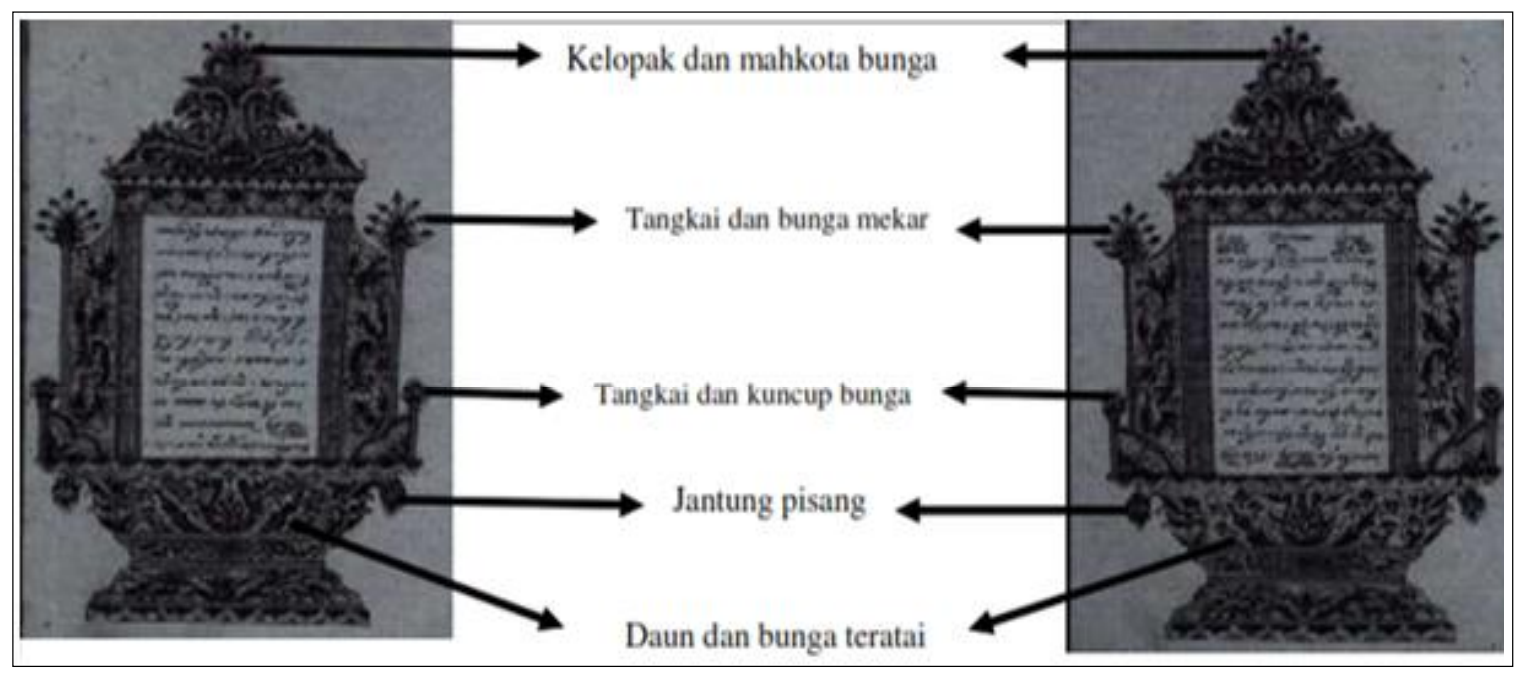

Gambar 1. Iluminasi Wedana Milir Kapatyan

ialah terciptanya babad Pecinna yang memuat isi yang bermanfaat dan penuh dengan keindahan. Bagian di bawahnya sebelah sisi kanan dan kiri terdapat tangkai dan bunga mekar, jika disesuaikan dengan isi teks melambangkan adanya keindahan dalam cerita tersebut seperti watak baik Tumenggung Jaganegara. Bunga yang mekar menandakan waktu kejayaan Tumenggung Jaganegara saat ia memerintah kerajaannya. Selain itu, simbol bunga yang mekar ini menjadi sebuah harapan agar Tumenggung Jaganegara akan selalu berjaya bak bunga yang senantiasa bermekaran.

Terdapat gambar tangkai dan kuncup bunga di bagian bawah dari gambar iluminasi. Tangkai dan kuncup bunga tersebut sesuai dengan isi teks melambangkan bahwa sebelum mekar ia mengalami masa kuncup. Kuncup bunga ini menandakan bahwa suatu sat bunga itu akan mekar. Artinya, dalam memerintah suatu kerajaan, ada masanya ketika kerajaan itu baru saja berdiri dan senantiasa berharap suatu saat nanti kerajaan tersebut dapat berkembang menjadi besar dan memiliki kejayaan. Kuncup bunga akan selalu menandakan adanya kehidupan bunga itu sendiri. Begitu pula dengan kejayaan sebuah kerajaan akan selalu ada jika kerajaan tersebut dipimpin oleh seseorang yang berkarakter baik dengan memiliki kesucian hati.

Timotru (2016: 125) menjabarkan tentang delapan laku baik pemimpin disimbolkan sebagai bumi, angin, api, air, angkasa, matahari, bulan, dan bintang (bumi, geni, banyu, angin, langit, surya, candra, dan kartika).

Dewa Endra : Dermawan tak terbatas

Dewa Yama : Memberantas segala kejahatan

Dewa Surya : Memerintah bijaksana dan mengajak rakyatnya untuk hidup suci

Dewa Bayu : Berpikir cerdas dan teliti

Dewa Kuwera : Senang memberi pakaian makanan, tempat tinggal dan hiburan bagi rakyat

Dewa Baruna : Menyelesaikan segala permasalahan sesulit apapun

Dewa Brama : Menjunjung tinggi kebenaran dan keadilan serta memiliki semangat membara untuk memberantas kejahatan. 
Menurut delapan laku baik pemimpin di atas, dapat diketahui bahwa seorang pemimpin harus memiliki hati yang suci agar dapat mengajak rakyatnya untuk hidup suci pula. Pemimpin yang suci hatinya adalah pemimpin yang memiliki kemurnian moral. Di dalam hatinya tidak memiliki maksud terselubung, melainkan murni hanya untuk rakyat serta Tuhannya. Kesucian hati Tumenggung Jaganegara digambarkan dengan iluminasi pada bagian paling bawah. Dalam iluminasi tersebut terdapat gambar daun dan bunga teratai. Teratai melambangkan sebuah kesucian, sesuai dengan isi teks memungkinkan bahwa kesucian yang dimaksud ialah kesucian hati seorang pemimpin. Berdasarkan iluminasi tersebut pendidikan karakter sebagai pembentuk karakter bangsa adalah karakter kepemimpinan yaitu sebagai seorang pemimpin hendaknya memiliki kesucian hati. Iluminasi wedana milir kapatyan dapat dilihat pada Gambar 1.

Karakter kesucian hati ini juga nampak pada simbol rusa (Gambar 3). Orang Tiongkok percaya bahwa binatang rusa memiliki umur yang sangat panjang sehingga dijadikan lambang panjang umur atau dewa kehidupan (Mulyono, 2008: 7). Binatang ini dianggap satusatunya binatang yang dapat memperoleh cendawan suci dari keabadian. Tanduk rusa memiliki nilai yang sama. Oleh karena itu, rusa seringkali melambangkan kesucian dan bebas dari kontaminasi dunia yang cemar (Williams, 974: 115-116). Dari pengertian tersebut maka gambar rusa bersayap melambangkan kesucian hati sosok Ngabdul Rahmanu Sayidin Panatagama ke-3. Rusa juga terkenal dengan kecepatannya dalam berlari. Hal ini menunjukkan bahwa seorang raja juga harus memiliki kecepatan dalam bergerak membesarkan kerajaannya. Dengan beraneka ragam inovasi yang dilakukan oleh seorang pemimpin tentu kerajaannya akan segera berkembang menjadi lebih besar.

Pada Gambar 3 juga dimunculkan kembali lambang karakter berani yang nampak pada gambar kepala banteng. Karakter kepemimpinan yang tertuang pada iluminasi berupa kepala banteng sebagai lambang kekuasaan senopati yang disegani di tanah Jawa. Dalam berbagai budaya, banteng merupakan simbol dari suatu kepentingan yang besar. Banteng memiliki kekuatan yang sangat besr dan hebat sehingga banteng merupakan simbol dari kekuatan dan semangat (Oentoro, 2012: 54). Tanduk dari banteng dapat melambangkan bulan sabit, karena bentuk tanduk yang mirip dengan bentuk bulan sabit. Kepala banteng juga muncul sebagai salah satu lambang dari pancasila, yakni kedaulatan yang dipimpin oleh hikmat kebijaksanaan dalam permusywaratan perwakilan. Kepala banteng digunakan sebagai lambang sila keempat karena banteng merupakan salah satu fauna (binatang) Indonesia yang dikenal kuat serta tangkas. Banteng memiliki sikap tak mau mengganggu, tapi apabila diganggu, dilukai akan berontak/mengamuk. Hal ini melambangkan kekuatan, kedaulatan rakyat Indonesia seluruhnya atas negara Republik Indonesia yang gagah berani karena kebenaran. Sesuai dengan konteks yang terdapat dalam teks Babad Pecinna bahwa kepala banteng ini melambangkan sikap Pakubuwana yang memiliki kekuatan sehingga terlihat gagah berani. Ia merupakan sosok yang berani membela ketidakbenaran yang terjadi di lingkungan kerajaannya sehingga ia dapat memakmurkan Kerajaan Mataram yang dipimpinnya.

\section{Karakter Kerendahan Hati}

Kerendahan hati adalah salah satu sifat karakter yang mulia. Orang yang 
rendah hati tidak akan mudah menyombongkan diri atas segala hal yang telah dimiliki atau dicapainya. Walaupun orang tersebut sudah sukses ia akan tetap bersikap merendah dan merasa belum mampu sehingga ia akan terus belajar sepanjang hidupnya. Karakter kerendahan hati ini penting sekali dimiliki oleh seorang pemimpin, karena ia harus selalu mengayomi rakyatnya. Kekuasaan yang didapatkannya tentu tidak akan lepas dari dukungan rakyatnya. Oleh karena itu, sudah sepantasnyalah seorang pemimpin memiliki karakter rendah hati.

Orang yang memiliki sifat rendah hati akan disenangi banyak orang. Kesahajaannya membuat orang lain mengagumi perilakunya. Dengan demikian, hidupnya akan menjadi damai, tentram, dan mampu menjauhkan adanya perselisihan. Orang yang rendah hati akan selalu didoakan oleh orang banyak sehingga kehidupannya akan semakin makmur dan berjaya.

Endraswara (2013: 25) menuturkan, atas dasar falsafah kepemimpinan Jawa prasaja dan ajur-ajer, maka pegangan pokok pemimpin yaitu falsafah: (1) aja gumunan, (2) aja kagetan, dan (3) aja dumeh. Falsafah aja gumunan ini mengajarkan pemimpin untuk bersifat tenang dan berwibawa, tidak terlalu terheran-heran dengan suatu hal. Bila pemimpin senang heran, akan memunculkan rasa ingin yang kadang-kadang menempuh jalan pintas. Heran itu penting, tetapi kalau berubah menjadi terheran-heran sering kurang wajar. Falsafah kepemimpinan aja kagetan, adalah rasa tidak menunjukkan sikap kaget jika ada hal di luar dugaan, dan tidak boleh sombong. Falsafah ini bukan berarti pimpinan itu anti kemajuan. Kaget adalah kondisi jiwa yang kurang wajar dan seimbang. Pimpinan yang tidak mudah kaget menyaksikan berbagai hal.
Falsafah aja dumeh sering menjadi bumerang bagi seorang pimpinan. Seringkali pimpinan merasa sebagai keturunan ningrat, mantan menteri, dan sebagainya. Rasa berbangga diri dengan menepuk dada, sebenarnya hanya dilakukan oleh pemimpin yang gila jabatan. Lebih membahayakan lagi kalau pimpinan terlalu tergila-gila jabatan, seringkali lupa diri. Berbeda dengan pemimpin yang mengetahui tentang diri sendiri, kekurangan dan kelebihan tentu menjadi modal dalam memimpin bangsa ini. Ketika dumeh itu yang berkembang pada diri pemimpin, buahnya adalah kesombongan diri. Pimpinan demikian biasanya kurang sukses, karena hanya akan menjadi nerkhisus. Pemimpin yang merasa sukses sendiri, tinggal menunggu waktu, tentu akan tergeser. Biarpun pergeseran seorang pimpinan itu wajar, namun kalau belum saatnya sudah geser seringkali menyakitkan. Dari uraian di atas dapat disimpulkan bahwa syarat pemimpin salah satunya bersikap rendah hati dan tidak sombong.

Karakter kerendahan hati ini dalam iluminasi naskah Babad Pecinna dapat dilihat dari simbol gambar jantung pisang. Pada bagian bawah wedana renggan milir kapatyan terdapat pula gambar jantung pisang. Jika dihubungkan dan dibaca dari bawah, gambar tersebut menunjukkan pola kehidupan, dari jantung pisangbunga kuncup-bunga mekar-mahkota dan kelopak bunga yang besar.

Bunga jantung pisang sendiri melambangkan kerendahan hati, kebersihan budi, dedikasi, keihklasan dan juga fase seseorang akan meraih kejayaan. Warna kulit jantung pisang pada umunya adalah merah. Warna merah pada kulit jantung pisang ini menunjukkan bahwa manusia yang baru keluar dan baru memiliki ilmu pengetahuan akan merasa jika dirinya lebih dibanding orang lain. Hal ini terlihat 
pada isinya sangat begitu kecil dan masih penuh dengan getah dan teksturnya cukup alot. Jika dikupas terus menerus hingga terdalam, akan ada lapisan putih (Galuh, 2017).

Lapisan kulit dari yang awalnya merah ke putih bersih itu sebagai satu pertanda terbukanya seluruh hijab-hijab yang membelenggu manusia. Warna merah yang melambangkan angkara akan berubah menjadi putih ketika terbukanya seluruh hijabnya. Warna putih yang terlihat akan menunjukkan kerendahan hati, kemuliaan hati, serta dekatnya diri pada Sang Pencipta.

Ketika bunga jantung telah terbuka satu persatu disitulah mewujud benih buah pisang yang masih berwarna hijau dan belum muncul isi buah tersebut. Hal ini mengibaratkan orang yang sedang menjalani kehidupan dalam masa muda. Pada waktu itulah mereka akan mengalami pertumbuhnan, jatuh bangun, merasakan getah sepatnya dunia yang diwujudkan dengan buah pisang yang masih muda, masih penuh dengan getah dan belum dapat dipanen karena masih sepat.

Bunga jantung pisang ini jika dikaitkan dengan isi kandungan teks menceritakan kehidupan Tumenggung Jaganegara yang tersohor dengan watak baiknya, yakni kerendahan hatinya sebagai seorang pemimpin. Ia selalu hidup sederhana dan tidak menampakkan kekayaannya dalam menjaga keselamatan dan ketentraman negara. Jantung pisang merupakan awal dari kebermanfaatan buah pisang. Layaknya jantung pisang yang melambangkan kerendahan hati, seseorang yang memiliki watak demikian tentu akan bermanfaat bagi orang lain, seperti pemimpin yang bermanfaat bagi rakyatnya.

\section{Karakter Berani}

Seorang pemimpin harus memiliki sifat gagah dan berani. Seorang pemimpin yang berwibawa akan membuat orang segan padanya. Jika seorang pemimpin tidak memiliki wibawa, maka bawahannya tidak akan patuh terhadap perintahnya dan dia akan diremehkan oleh lawannya. Dalam Babad Pacinna ditemukan iluminasi/ rerenggan yang termasuk dalam jenis wedana gapura renggan. Isi Teks Sêrat Babad Pecinna pada halaman 255-256 ini menceritakan tentang tidak ada yang dapat menolak takdir bahwa Mangku Negara Sayidin Panatagama sebagai senapati perang. Gambar rerenggan di dalam teks ini meliputi naga raja yang melambangkan Mangku Negara Sayidin Panata Gama, Senapati perang yang tidak menolak takdir.

Naga merupakan simbol dari kekuatan yang tidak terbatas dan juga tentang perlindungan yang harus dilakukan oleh seorang pemimpin kepada rakyatnya. Dalam teks tersebut simbol naga merepresentasikan kekuatan Mangku Negara Sayidin Panatagama ketika memerintah kerajaannya. Kekuatan yang tak terbatas yang dimilikinya itulah yang mendasarinya memiliki keberanian yang luar biasa untuk berjuang membesarkan kerajaannya. Naga raja juga menggambarkan karakter yang baik pada seorang pemimpin yaitu berwibawa, sehingga disegani oleh rakyat dan musuhmusuhnya.

Sifat kepemimpinan gagah berani merupakan salah satu sifat dasar yang wajib dimiliki oleh pemimpin. Endraswara (2013: 43-44) menjabarkan tentang sifat kepemimpinan Gajah Mada berdasarkan Kitab Dasa Dharma Sastera sebagai berikut. (a) Rajin sujud, meditasi atau samadhi. Laku sujud atau disebut manembah, selalumenjadi landasan bertindak. Memimpin yang disertai sujud, akan ingat 
selalu pada Sang Pencipta, sehingga tidak gegabah dalam bertindak. (b) Awas artinya menjadi pelopor dan memiliki wawasan ke depan. (c) Greget artinya tokoh pimpinan yang menjadi sumber motivator bawahan. Pimpinan yang penuh greget, berarti mampu mendorong kemajuan bawahan. (d) Babar binuka artinya pemimpinan yang terbuka jauh lebih dihargai bawahan. (e) Lantip artinya pemimpin yang mampu menangani berbagai hal. (f) Sopan dan ramah. (g) Senantiasa menuntut ilmu pengetahuan. (h) Senantiasa melindungi warga dan mewujudkan kesejahteraan masyarakat, menegakkan keadilan. (i) Seorang pemimpin yang gagah berani, bertanggung jawab, dan tangguh dalam menghadapi berbagai masalah, tunduk kepada aturan (hukum). (j) Menghormati orang bijaksana, menghargai para pahlawan, dan senantiasa melakukan tapa brata dan semadhi.

Dari uraian di atas, dapat diambil poin yang menggambarkan tentang karakter kepemimpinan Mangku Negara Sayidin Panatagama yaitu gagah berani. Seperti yang digambarkan dalam naskah tersebut terdapat gambar meriam, pedang, dan tongkat yang melambangkan seorang pemimpin yang sekaligus sebagai senopati perang dengan karakteryang dapatmenjadi panutan yaitu gagah berani. Seorang senapati perang pasti memiliki sifat gagah berani sehingga ketika terjadinya perang ia mampu memimpin pasukannya untuk berjuang meraih kemenangan. Saat masa pemerintahan Mangku Negara ia dihadapkan pada berbagai macam konflik yang membuatnya harus berani berperang, terutama untuk melawan para penjajah. Hal ini harus dilakukannya demi memiliki kekuasaan yang utuh atas tahta kerajaan yang dipimpinnya. Tanpa keberanian yang menggelora mustahil ia dapat melawan dan mengalahkan para penjajah. Bentuk ular naga, pedang, meriam, dan tombak dapat dilihat pada Gambar 2.

\section{Karakter Kepemimpinan Berwibawa dan Disegani oleh Rakyat}

Rerenggan pada teks ini termasuk dalam jenis wedana gapura renggan. Isi Teks Sêrat Babad Pecinna pada halaman ini menceritakan bahwa Ngabdul Rahmanu Sayidin Panatagama kaping 3 diangkat menjadi Raja Surakarta Hadiningrat

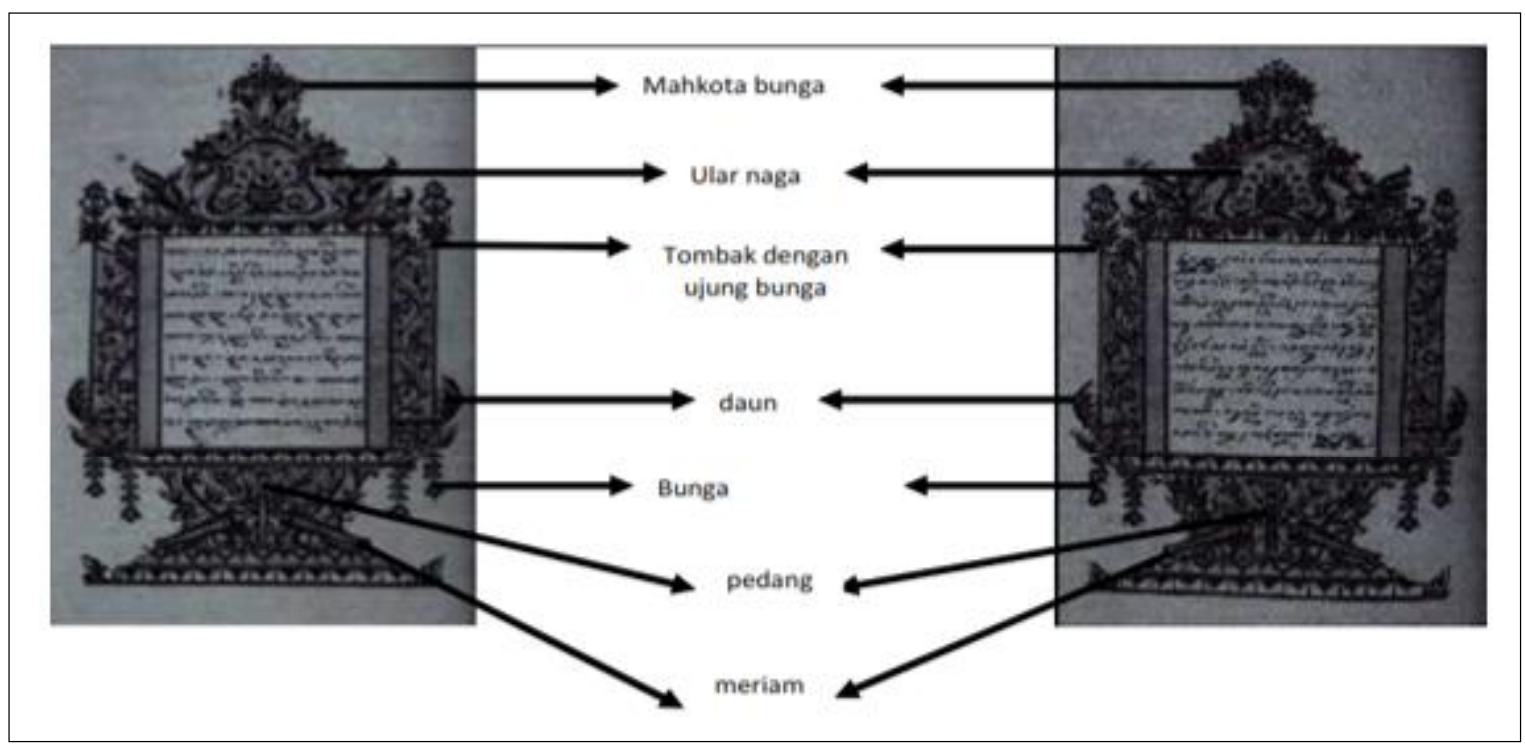

Gambar 2. Iluminasi Naskah Babad Pacinna Halaman 255-256 
dengan sebutan Pakubuwana sebagai senapati ing Ngalaga yang sangat disegani di tanah Jawa. Pada Gambar 2, karakter kewibawaan seorang pemimpin juga nampak dari gambar mahkota bunga. Mahkota merupakan simbol kewibawaan seorang raja yang sedang berkuasa. Sesuai dengan penjabaran teks bahwa raja yang berkuasa saat itu adalah Mangku Negara Sayidin Panatagama. Kemudian iluminasi mahkota raja yang terletak pada bagian paling atas yang melambangkan diangkatnya Ngabdul Rahmanu Sayidin Panatagama ke-3 menjadi raja Surakarta Hadiningrat dengan sebutan Pakubuwana.

Menurut Endraswara (2013: 72) seorang pemimpin harus memiliki sifat agung binathara, yang artinya orang yang benar-benar disegani. Ada dua tanda penting seorang pemimpin memiliki sifat agung binathara, yaitu (1) dapat menjaga kepaduan lisan dan perbuatan. Tindakan pimpinan adalah potret dari pemikiran. Tindakan yang dapat dihargai bawahan dapat disebut wong agung, artinya orang berjiwa besar; (2) dapat diteladani segala tindakannya, dapat menyenangkan rakyat, dan tidak pernah menyakiti rakyat.
Pimpinan semacam ini, akan disegani rakyatnya bukan atas dasar keterpaksaan, melainkan secara legawa atau ikhlas rakyat mencintai pemimpinnya. Rakyat ingin menjaga pemimpinnya dan atasan pun melindunginya.

Selanjutnya terdapat pula gambar lampu kerajaan yang diibaratkan sebagai sosok Pakubuwana yang dituakan dan disembah oleh rakyat se-Tanah Jawa, seperti lampu kerajaan yang menerangi kegelapan. Lampu pada dasarnya merupakan lambang dari penerangan. Artinya, seorang raja harus mampu menjadi penerang bagi rakyaatnya terutama ketika ada masalah yang melanda pemerintahnnya tersebut. Di sisi kanan dan kiri pada gapura terdapat isen-isen daun sulur sebagai sebuah gambaran kehidupan. Berdasarkan deskripsi iluminasi tersebut dapat diambil kesimpulan tentang pendidikan karakter yang tercermin adalah karakter kepemimpinan seorang raja sebagai Pakubuwana yang berkuasa dan sangat disegani oleh rakyatnya. Gambar 3 adalah deskripsi iluminasi halaman 263-264.

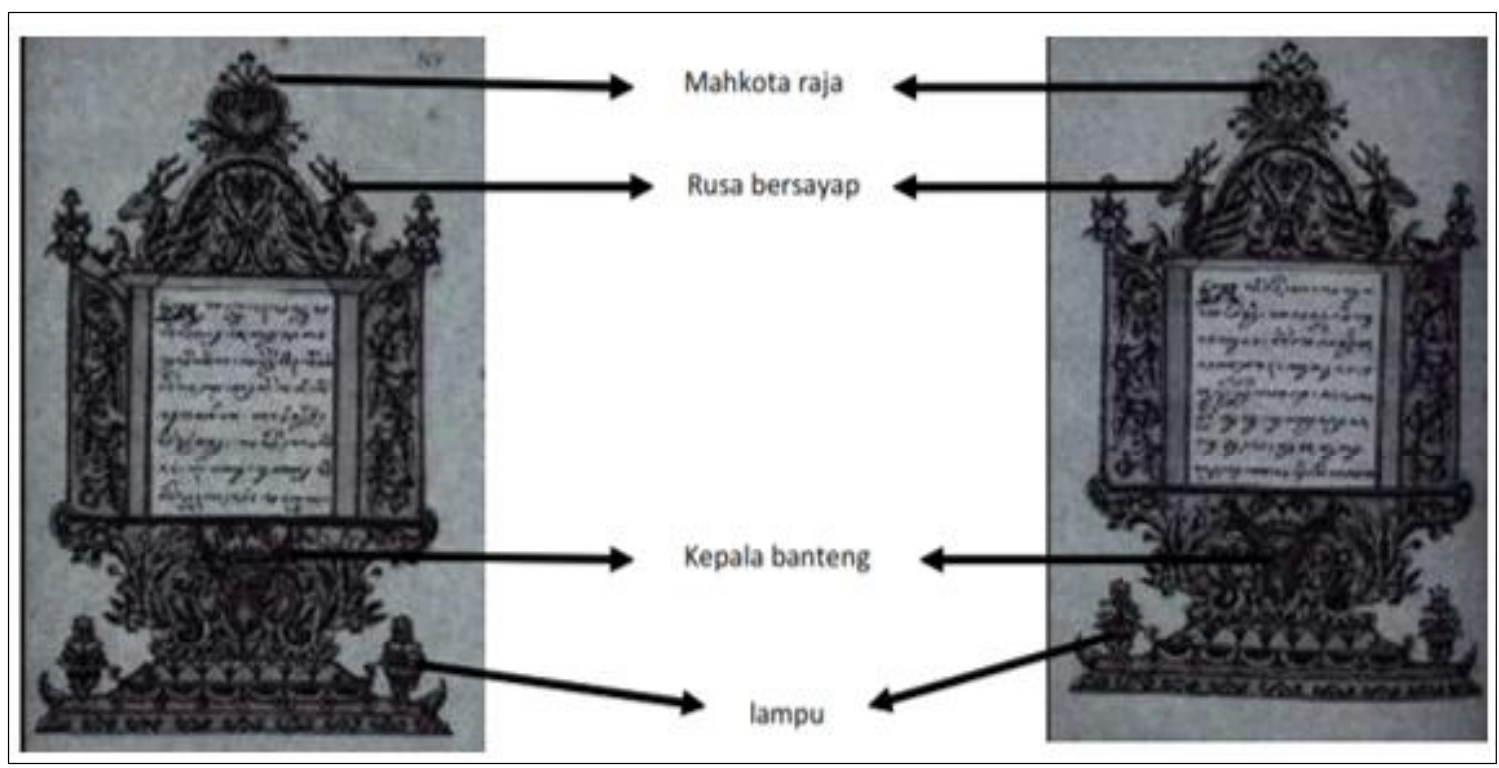

Gambar 3. Iluminasi Naskah Babad Pacinna Halaman 263-264 
Karakter Religius

Endraswara (2013: 43-44) menyatakan bahwa sifat kepemimpinan Gajah Mada berdasarkan Kitab Dasa Dharma Sastera salah satunya yaitu rajin sujud, meditasi atau samadhi. Rajin sujud artinya ia rajin beribadah (sholat). Orang yang senantiasa menjalankan sholat termasuk orang yang religius. Sifat religius (laku sujud/manembah) ini menjadi penting karena selalu menjadi landasan bertindak. Seorang pemimpin yang dalam kepemimpinannya disertai dengan sujud, akan ingat selalu pada Sang Pencipta, sehingga tidak gegabah dalam bertindak.

Dalam naskah Babad Pacinna karakter religius ini Tampak pada gambar jamang susun tiga. Jamang susun tiga ini merupakan lambang raja sekaligus menandakan bahwa ia adalah ahli agama. Jamang adalah aksesoris yang melingkari irah-irahan terbuat dari kulit. Pada tokoh Raden Gathutkaca menggunakan jamang cringih susun tiga. Bentuk jamang ini terdapat tiga lapisan. Sebagian besar tokoh pada wayang wong gaya Yogyakarta menggunakan jamang cringih terutama tokoh kesatria. Di dalam tata busana wayang purwa, jamang susun tiga ini biasa digunakan oleh kesatria yang kedudukannya setara dengan raja, atau putera mahkota. (Prasetyo, 2012: 40) Jika dihubungkan dengan isi teks tersebut bahwa kesatria yang dimaksud menggunakan jamang susun tiga ini adalah Pakubuwana sebagai senapati ing Ngalaga yang sangat disegani di tanah Jawa.

\section{SIMPULAN}

Berdasarkan uraian di atas tentang makna simbolik pola iluminasi dalam teks Babad Pacinna sebagai pembangun karakter bangsa dapat disimpulkan bahwa pola iluminasi dalam Babad Pacinna berjenis wedana gapura renggan, yang di dalam Naskah Babad Pacinna terdapat enam iluminasi/rerenggan yang berpasang-pasangan menjadi tiga pasang. Dari ketiga pasang rerenggan tersebut yang mempunyai nama ada satu pasang yaitu wedana milir kapatyan pada halaman $4 \mathrm{v}$ dan 4r. Sedangkan dua pasang yang lainnya yaitu pada pasangan halaman 255256 dan 263-264 tidak bernama.

Pendidikan karakter karakter yang dominan dalam iluminasi Naskah Babad Pacina adalah karakter kepemimpinan, yang menggambarkan sebagai seorang pemimpin yang berwibawa, pemberani, rendah hati, serta mempunyai hati yang suci. Selain itu di dalam Babad Pacinna ini juga mempunyai ajaran pendidikan karakter cinta kepada Tuhan (religius), yang di dalam teks Babad Pacinna dideskripsikan sebagai seorang pemuka agama yang taat kepada Tuhan, sebagai seorang pemimpin yang berkuasa masih selalu ingat dan taat kepada Tuhan. Dalam Hal ini menggambarkan bahwa di atas langit masih ada langit sebagai penggambaran sebagai seorang pemimpin dalam posisi tertinggi tidak lupa diri dan masih berserah diri kepada Tuhan.

\section{DAFTAR PUSTAKA}

Baried, S. B. 1985. Pengantar Teori Filologi. Jakarta: Pusat Pembinaan dan Pengembangan Bahasa, Departemen Pendidikan dan Kebudayaan.

Behrend, T. E. 1990. Katalog Induk Naskahnaskah Nusantara Jilid I: Museum Sonobudoyo Yogyakarta. Jakarta: Djambatan.

Bland, D. 1969. A History ofBook Illustration: the Illuminated Manuscript and the Printed Book. London: Faber and Faber Limited.

Damayanti, N., \& Suadi, H. 2009. Ragam dan Unsur Spiritualitas pada Ilustrasi Naskah Nusantara 18001900-an. Diunduh dari http://www. wacananusantara. org/content/ 
view/category/1/id/382, pada 1 April 2012.

Djamaris. 2003. Metode Penelitian Filologi. Jakarta: CV Manasco.

Endraswara, S. 2013. Falsafah Kepemimpinan Jawa. Yogyakarta. Narasi

Folsom, R. 1990. The Calligraphers Dictionary. London: Thames and Hudson.

Galuh, T. 2017. Menggali Makna Hidup dalam Filosofi Tombak Sigar Jantung Pamor Wengkon Isi. Diunduh dari http://www.akasara.com/2017/06/ menggali-makna-hidup-dalam-filosofi. html?m=1, pada 21 Oktober 2017 .

Koesoema, A. D. 2007. Pendidikan Karakter: Strategi Mendidik Anak di Zaman Global. Jakarta: Grasindo.

Lickona, T. 2013. Pendidikan karakter panduan lengkap mendidik siswa menjadi pintar dan baik. Bandung: Penerbit Nusa Media.

Mu'jizah. 2009. Iluminasi dalam Suratsurat Melayu Abad ke-18 dan ke19. Jakarta: KPG, Ecole Francaise d'Extreme-Orient, Pusat Bahasa, dan KITLV.

Mulyono, G., \& Thamrin, D. 2008. "Makna Ragam Hias Binatang pada Klenteng Kwan Sing Bio di Tuban". Jurnal Dimensi Interior, 6(1), 1-8.
Oentoro, Y. 2012. "Representasi Figur Garuda yang Digunakan sebagai Lambang Negara". Jurnal Nirmana, 14(1), 47-64.

Safari, A. 0. 2015. "Iluminasi dalam Naskah Cirebon". SUHUF Jurnal Pengkajian Al-Qur'an dan Budaya, 3(2), 309-325. Saktimulya, S. R. 1998. "Fungsi Wedana Renggan dalam Sestradisuhul". Tesis. Program Studi Sastra Indonesia dan Jawa, Program Pascasarjana UGM, Yogyakarta.

Saktimulya, S. R. 2012. “Memaknai Sěstradi melalui Iluminasi Naskah Koleksi Pura Pakualaman". Makalah Simposium Internasional Pernaskahan Nusantara XIV, 11-13 September 2012 di UGM.

Suherman, W. S. 2014. Pemanfaatan Dolanan Anak dalam Pengembangan Karakter Anak. Yogyakarta: UNY Press.

Timotiu. 2016. Kepemimpinan dan Kepengikutan: Teori dan Perkembangannya. Yogyakarta: CV. Andi Offset.

Williams, C. A. S. 1974. Chinese Symbolism and Art Motives. Tokyo: Charles E. Tuttle Company.

Zuriati. 2010. "Iluminasi Naskhah-naskhah Minangkabau”.Jurnal Filologia Melayu, 17, 51-71. 